Torben Kragh Grodal

\title{
Fiktion som moderne mentalt software
}

Omkring 1810 opfandt den amerikanske læge Benjamin Rush "The tranquilizing chair«, beroligelsesstolen', som man kan se på billedet. Subjektet forhindres i at have nogensomhelst muskelaktivitet når det er placeret i stolen, med undtagelse af muskelkontrollen over øjnene, idet dog også synsfeltet er indskrænket af den store træblok der omslutter hovedet. Navnet på stolen antyder at formålet med stolen ikke var at den skulle vare et straffeinstrument selvom den måske kunne opleves således af den person, der var fastspændt til stolen. Stolen var sandsynligvis tænkt som en terapeutisk rekvisit. Et givet subjekt skulle ved

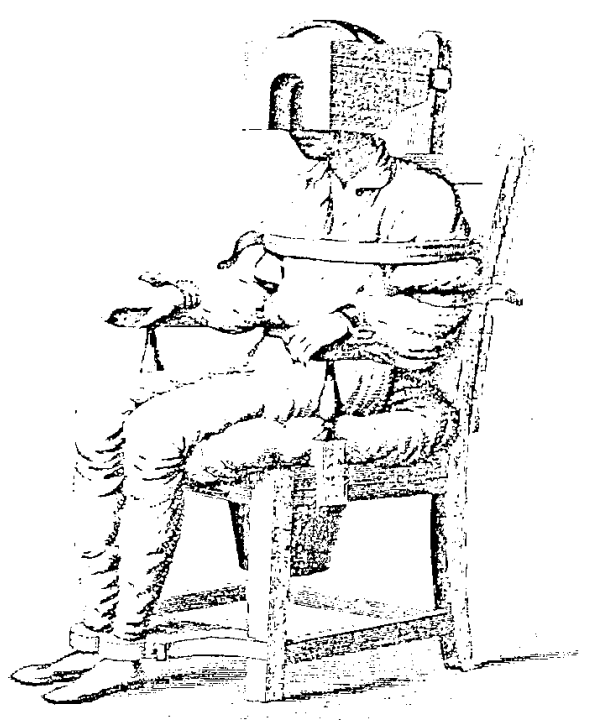
hjælp af stolen helbredes for en for voldsom motorisk aktivitet og vænne sig til en blot intellektuel eller perceptorisk aktivitet.

At omforme motorisk aktivitet til intellektuel og perceptorisk aktivitet er et vigtigt aspekt af civilisationsprocessen, og jeg vil senere uddybe sammenhængen mellem beroligelsesstolen og den civilisationsproces der fører frem til det moderne menneske. Men først vil jeg knytte nogle bemærkninger til en anden gruppe af beroligelsesstole, nemlig de stole der benyttes når man stille sidder og læser eller tænker. Ved overgangen fra de præ-moderne til de moderne samfund er der sket en voldsom forøgelse af den mængde af tid, der bliver brugt til at sidde for sig selv næsten uden muskelaktivitet og med en meget begrænset sansemæssig aktivitet. Den læsende bruger dele af synet, men 
ikke følesans, smagssans, lugtesans eller høresans. Den beroligede læser finder man overalt i de moderne samfund; i private hjem, i tog, universitetsbiblioteker, kontorer osv. finder man hende eller ham siddende opslugt på en stol. Men i modsætning til personen i Mr. Rush's stol er læseren bundet til sin stol af usynlige remme og bånd. Tryllebundet stirrer læseren på endeløse kombinationer af 28 bogstaver $\mathrm{i}$ sort på hvidt. Selvom denne aktivitet har eksisteret $\mathrm{i}$ adskillige tusind år var det kun i det attende og det nittende århundrede at læsning blev en masseaktivitet. I de moderne samfund er skolestartens tilvænning til stillelæsningens rolige abstraktion en af de markanteste initiationsriter. Set i et historisk perspektiv er læsning en ekstremt »abstrakt« beskæftigelse. Uden at henfalde til rousseauistiske forestillinger om det uspolerede »naturlige menneske «, er det evident at mennesket i tidligere samfund anvendte sit liv med aktiviteter, der medforte en langt mere omfattende anvendelse af sanserne og det muskulære apparat; aktiviteterne foregik yderligere i situationer med en langt mindre grad af kulturel formidling af den fænomenologiske fusion af subjektet og omverdenen. Selv kommunikationen af hvad der senere blev til »litteratur «, foregik i personaliserede kommunikationssituationer i modsætning til det moderne fiktionskonsum, der er karakteriseret ved ensom individualisme og ved den abstraktion der er forbundet med læsningens (og »kikningens«) abstrakte mediationer til omverdenen.

I det tyvende århundrede har læsningen fået konkurrenter med hensyn til hvilke aktiviteter man kan udføre, mens man sidder $\mathrm{i}$ beroligende stole. Fremkomsten af film, radio, fjernsyn, plader, bånd og computerskærme har medfort en voldsom forøgelse af mulighederne for ensomme stole-aktiviteter. Blandt de forskellige rolige aktiviteter ind tager konsumet af fiktion og nærtbeslægtede æstetiske aktiviteter en særlig plads, fordi beskæftigelsen formodes at være tilfredsstillende og at have sit mål i selve den rolige konsumsituation. At læse eller se på fiktion er lystfyldte aktiviteter der netop er karakteriseret ved at foregå med kroppen anbragt i stille isolation i stolen, adskilt fra andre interaktionsformer og stole-transcendente formål - selvom fiktion selvfølgelig kan og bliver pålagt opgaver af didaktisk karakter såsom at være led i en social og karaktermæssig dannelsesproces f.eks. ved at udvide læserens horisont. Ikke-fiktive læseprocesser er derimod hyppigt midler til »praktiske« mål der ligger uden for selve kroppens og bevidsthedens ophold i beroligelsesstolen.

Umiddelbart ser det ud som om formålet med opholdet i stolen er at undertrykke kroppen og dens motoriske subjektivitet med det formål at skabe »åndelighed«, forstået som sanse-og-bevidsthedsproces- 
ser der er løsrevet fra en umiddelbar sammenhæng med en handlende og umiddelbart omverdenssansende kropslighed. Åndelighed og stillesidning har historisk set været tættere forbundet med de højere klasser og deres adfærdsformer, livsanskuelser og finkultur end med de lavere klasser og deres massekultur. Sejren for den borgerlige kultur i slutningen af det attende århundrede betød en kraftig styrkelse af skellet mellem de lavere manuelt arbejdende klassers kropsbaserede æstetik og de borgerlige lags intellektualisme og åndelighed. Dette er mest iøjnefaldende indenfor musikken. Borgerskabet sad lyttende i koncertsale på en måde, der kunne bringe én til at tro at de led af en kraftig paralysering af det motoriske system, mens de samtidig blev stærkt mentalt »bevægede« af Beethovens, Brahms' eller Wagners værker. Først efter afslutningen af oplevelsen havde tilhørerne tilladelse til et kontrolleret afløb for de opbyggede spændinger $i$ form af retten til at klappe. For de lavere klasser derimod var musik og kropslig bevægelse snævert sammenknyttet som dansemusik. ${ }^{2}$

Mentalitetshistorikere har beskrevet den civilisationsproces ved hvilken det moderne menneskes perceptioner og handlinger har făet deres nuværende struktur. For eksempel har Walter Ong beskrevet udviklingen fra en mundtlig kultur til en kultur i hvilken sprog og kommunikation er baseret på det trykte ords fikserede visuelle eksistens i bogen. Ong har i bogen Orality and Literacy ${ }^{3}$ givet et omfattende resumé af forskning på dette område. Den historiske formning af den visuelle perception er blandt andre blevet udforsket af Erwin Panofsky. ${ }^{4} \mathrm{Og}$ en almen ramme for forståelse af civilisationsprocessen er blevet udarbejdet af Norbert Elias. ${ }^{5}$ I bogen History of Bourgeois Perception ${ }^{6}$ har den amerikanske historiker Donald $\mathrm{M}$. Lowe opsummeret en række hovedtræk af forskningsresultaterne inden for udforskningen af den historiske formning af den menneskelige perception.

Ifølge Lowe var samfundene i middelalderen stadig hovedsageligt baserede på mundtlighed, og middelaldermenneskenes forhold til omverdenen var i meget høj grad baseret på relativt nære sanser som høresans og følesans (og jeg vil tilføje smagssansen), hvorimod fjernsansen par excellence, synssansen, spillede en langt mindre rolle end idag. Men med renaissancen og den revolutionerende fremkomst af det trykte ord, Gutenberg-galaksen som McLuhan har døbt den, begyndte en proces som indebar at perceptionen af betydning og af »virkelighed« i stigende grad blev baseret på synet. Sandheden og virkeligheden bestod ikke mere af de fænomener som man selv havde rørt ved eller selv hørt om, men af hvad der kunne ses på de industrielt producerede bogsider, hvorpå sandheden om virkeligheden var 
fikseret. Denne proces accellererede i det sekstende og det syttende århundrede. Trykte bogstaver og visuelle diagrammer blev vigtige steder for virkelighedsfremstilling, og virkeligheden blev således noget der blev konstrueret derude i rummet og efterfølgende sanset af synssansen.

Henimod slutningen af det attende århundrede blev det enevældige gods(ejer)samfunds mere statiske fremstillingsformer omformet til mere dynamiske fremstillinger af virkeligheden. Samfundet blev ikke i mindre grad baseret på synet og på visuelle fremstillinger (tværtimod), men disse visuelle fremstillinger (i rum) skulle nu repræsentere dynamiske fremstillinger i tid. Som det er velkendt fra Michel Foucault's Les Mots et les Choses ${ }^{8}$, var det nittende århundredes borgerlige samfund næsten tvangsmæssigt optaget af processuelle og udviklingsmæssige fænomener, af diakroni.

Slutningen af det attende århundrede blev også præget af, hvad man kunne kalde en fiktions-eksplosion. Antallet af fiktionsværker der blev skrevet og trykt voksede dramatisk, og det samme gjorde antallet af læsere, understøttet af ekspansionen af læsefærdighed i nye lag af samfundet. Men der pågik ikke alene en kvantitativ ekspansion af produktion og forbrug, også fiktionens kvalitative side, dens indhold, ændrede karakter; vigtige træk ved den moderne fiktions mønstre - f.eks. genrekarakteristika - så dagens lys i førromantikken og romantikken. Genreformler såsom »gotisk « skræk-fiktion, melodramaet, den romantiske kærligheds-og følelsesroman og den moderne version af det lyriske digt blev konstruerede i denne periode, hvortil der kort tid efter kom mønstrene for den moderne kriminal-fiktion (udviklet af E.A. Poe). Alle disse genrer er karakteriseret ved, at de forsøger at frembringe stærke følelser, og for eftertiden er fænomenet romantik uløseligt forbundet med fremstillingen af emotioner. Hvad forårsager alle disse fænomener?

Tressernes medie-profet, Marshall McLuhan, formulerede slagordet "The Medium is the Message ${ }^{9}$ Hvis vi skal benytte denne slagordsagtige formulering til at kaste lys over fremkomsten af emotionsfremkaldende fiktionsgenrer og over forøgelsen af fiktionsforbruget vil det betyde, at vi skal søge aspekter af en forklaring i mediets, dvs. den trykte bogs karakteristika. Som omtalt ovenfor betød fremkomsten af den trykte bog at synssansen, der er karakteriseret ved at være en fjernsans, der skaber distance og objektivering, blev den fremherskende sans. Hvis derfor bogmediets meddelelse skulle være mediet, ville dens meddelelse være objektivering og distance. Ydermere forstærkes den abstraktion, der allerede ligger i sprogliggørelsen af verden, ved sprogets alfabetiske repræsentation. Således har Ro- 
man Jacobson i Linguistics and Poetics understreget det trykte ords relative fattigdom i forhold til det talte. Som et eksempel herpå omtaler han en russisk skuespiller som var i stand til at udtale en given sætning på halvtreds forskellige måder med hver deres specifikke betydninger og konnotationer. ${ }^{10}$ Men det trykte sprog har kun én måde at repræsentere de halvtreds forskellige mundtlige budskaber på. Normalt har den trykte bog yderligere en oplevelsesfattig og stereotyp visuel fremtræden, og den tillader ikke læseren at verificere dens visuelle meddelelser ved føle-, lugt-, eller smagssans.

Marshall McLuhan siger yderligere at et givet mediums indhold vil være det dét foregående medium, som et givet medium forsøger at erstatte. Overført på bogmediet vil dette betyde, at indholdet af det abstrakte og objektiverede visuelle bogmedium skulle være sanseligheden i talen (og indpakket $\mathrm{i}$ talen de perceptoriske oplevelser som talen repræsenterer). Uden fuldt at acceptere denne tankegang kan den ikke desto mindre som hypotese forsyne os med en nøgle til forståelsen af beroligelsesstolens og den trykte fiktions "gåde«. Hvis vi tænker på den tradtionelle opfattelse af, hvorledes litteraturen ændredes $\mathrm{i}$ anden halvdel af det attende århundrede, det tidspunkt hvor det »abstrakte« og »objektive« bogmedie ekspanderede, og hvor litteratur $\mathrm{i}$ den moderne såvel som $\mathrm{i}$ den »bogstavelige « betydning ${ }^{11} \mathrm{op}-$ stod, er objektivering og distance bestemt ikke de forste karakteristika der falder én ind. Præ-romantikken og romantikken bliver mest beskrevet som perioder i hvilke stærke følelser, begær og lidenskaber og stærke udtryk for individualisme og subjektivitet blev fremherskende inden for kunsten og særlig inden for musik og litteratur. Yderligere var det perioder i hvilke en ny folelse for naturen og det overnaturlige blev fremstillet i kunsten. Slutteligt, og tilsyneladende paradoksalt, var perioderne karakteriserede ved idealisering, og dette fænomen peger på abstraktionsproblematikken, skabelsen af en distance mellem form og det der bliver betydet af den abstrakte form. Forstået med McLuhanske begreber bliver indholdet af det abstrakte og »objektive « trykte fiktionsmedie de for egående mundtlige (og perceptoriske) medier.

Periodernes kunstproduktion var strukturelt set karakteriserede ved to tilsyneladende modsatte tendenser. På den ene side gik det narrative, handlingskonstruerende håndværk i præromantikken og romantikken frem med stormskridt. I musikken fik man de til tider mere en en time lange orgiastiske »fortællinger« som vi finder dem hos Beethoven og hans efterfølgere, og i litteraturen udarbejdedes den moderne romanlange suspense-fortælling. Suspense-fortællingen erstattede i stort omfang tidligere tiders episodiske strukturer som 
man f.eks. finder i den pikareske roman. En række romaner blev således opbygget på basis af en hidtil ukendt spændingsskabende fortælleteknik, der var baseret på metonymisk udskydelse og sublimering. På den anden side var perioderne karakteriseret ved en stærk interesse i lyrik og små, intense fremstillinger af følelser og synæstetiske oplevelser, baserede på metaforiske og symbiotiske relationer. Førromantikkens og romantikkens handlings-drive synes at simulere en ikke-visuelt oplevet verdens dynamik, en handlings-og folelsesverden. Mentalitetshistorikeren Walter Ong har karakteriseret de mundtlige kulturer med udtrykket "verbo-motor lifestyle « med hvilket han mener at de mundtlige kulturer var prægede af en konkret menneskelig interaktion, baseret på motoriske handlinger. ${ }^{12}$ Ord var redskaber (og mønstre af muskelinnervationer), ikke repræsentationer. Men det er præcist det som ord ikke kan være når man læser fiktion. Ikke desto mindre ser det ud som om den "romantiske« spændingsfiktion gennem det trykte medium forsøgte at efterligne eller at simulere nogle af de træk der var karakteristisk for den mundtlige kultur (i modsætning til de foregående perioders mere repræsentative litteratur). I nogle henseender tog romantisk litteratur meget konkret mundtlig litteratur som sit forbillede. Romantiske forfattere forsøgte at overføre træk fra den »folkelige« fortælling og fra »folke«-visen til skreven litteratur; men samtidig muliggjorde det trykte medium langt større og mere komplicerede spændings-og udskydelsessystemer end for eksempel den »folkelige«, mundtlige fortælling. Samtidig blev den narrative spændingsskabende forskydning ofte - som hos Ann Radcliffe - kontrapunkteret af artikulationer af en metaforisk symbiose mellem Jeg og verden ved lyriske passager, hvor udskydelsen blev erstattet af nærvær eller umedierbart fravær.

At læse eller at frembringe fiktion var blevet en ensom beskæftigelse. Selv når fiktionen simulerede (inter)aktion og emotioner på de trykte sider, forbedrede det trykte medium mulighederne for individualisme ved at gøre det muligt for en stadig voksende mængde af mennesker at udtrykke sig selv og at få følelsesmæssige oplevelser uden at være nødt til at interagere med andre mennesker og med deres umiddelbare omgivelser. En betydningsfuld del af det nittende århundredes litteratur handler om lysten ved og problemerne ved at oplevelser og følelser artikuleres ved læsning og skrivning uden nogen umiddelbar virkelighedskontekst.

Det paradoksale budskab i megen skreven fiktion i forromantikken og romantikken synes således at være objektivisme og distance som vehikel for subjektivisme. Fiktionslæseren sidder i ensom majestæt og stirrer »derud«, ud i omverdenen repræsenteret ved bogens sider, 
men formålet er at lære subjektivismens og inderlighedens mysterier. Læserens opmærksomhed er rettet mod et mediationspunkt mellem jeg-et og den anden. Fra at bevidstheden er knyttet til en totalitet af de umiddelbare krops- og berøringssansninger og af den visuelle og motoriske formidling til omverdenen flyttes selv-bevidsthedens »sted « »ud« til bogens sider, hvorved der skabes en afstand til den umiddelbare kropsbaserede bevidsthed. Mentalitetshistorikere har argumenteret for at grunden til det forhold, at menneskene pludselig fik en indre psykologisk »dybde« $\mathrm{i}$ slutningen af det attende århundrede var at det i langt højere grad blev formet af dets læsning. At fremstille og at simulere følelserne derude, på siderne, er ikke kun et udtryk for subjektivisme, men i lige så stor grad et udtryk for objektivisme ved at skabe en større afstand mellem følelsernes udtryk derude og deres indhold (deres betydede) inde i kroppen. ${ }^{13}$ Frembringelsen af mental dybde og adskillelsen af bevidstheden fra kroppen var $\mathrm{i}$ nogle henseender en stærkere og mere fuldstændig gentagelse af det der skete i det gamle Grækenland, hvor læse-og-skrivefærdigheden medførte opkomsten af forestillingen om psyken og forestillingen om at form og idé var noget der var forskelligt fra den sansbare verdens totalitet. ${ }^{14}$ Skriftens fysiske udtryk er objektive og permanente, modsat lyden der usynligt og uden håndgribelige udtryksstørrelser bevæger sig fra afsender til modtager. Ved de fysiske udtryksstørrelsers placering i det ydre rum, fik det betydede, indholdet, sin transcendens som noget absolut der var helt forskelligt fra udtrykket. Betydningen var noget som psyken ved sin evne til tænkning uddrog af sansernes data og som eksisterede uafhængigt af kroppen, modsat den lydbårne betydning.

Skriftlighedens objektivisme skabte en tovejstrafik, især da den senere blev generaliseret ved brugen af den »upersonlige trykkekunst. Efterhånden som bevidsthedens forankring bevægede sig ud af kroppen og ud til siderne, der var placerede i det visuelle rum, bevægede det visuelle rums beboere sig den modsatte vej, ind i bevidstheden og det ubevidste. Dette er meget synligt i Freuds mentale teater, som i høj grad har det nittende århundredes litteratur som sin model. I dette mentale teater kæmper barnet ikke alene med den virkelige fader i den virkelige verden, men også mod en imaginær fader på den indre scene. Det psykiske rum har sine indre ødipale kampe, dets antropomorfe aktantielle struktur med et Jeg og et Over-jeg. der delvis er modelleret $i$ analogi med en ydre person og en ydre fader. Jeg-et bliver af Freud forstået som var det en person i rummet. Han beskriver endvidere i sin topologiske model dette indre rum, der har steder som bevidstheden, det forbevidste og det ubevidste. Det ydre 
rum og den ydre virkelighed bliver en slags skrift, der peger på en betydning der er placeret et andet sted. Et nyt rum fuld af aktører bliver så at sige skabt eller gjort synligt bag om ryggen af læseren eller den skrivende. At repræsentere krop og bevidsthed og dets følelser og lidenskaber derude er handlinger der kan opfattes som udtryk for en selv-distancering og »fremmedgørelse «. Den umiddelbare jeg-og-omverdens-oplevelse opsplittes dels i de fjerne ydre udtryk og dels i de lige så fjerne dybe indre indhold.

Denne selv-distancering og dette brud med de umiddelbare bånd til den fysisk nærværende anden (samtalepartneren) muliggjorde samtidig en ny udtryksfrihed. Mennesker kunne sidde i timevis og læse om og skrive om deres følelser og begær uden at skamme sig eller uden at engagere sig fuldt i disse. Rousseau's Les Confessions viste vej og angav klart forbindelsen mellem det at skrive/læse og det at befinde sig i skriftestolen. Her kunne man opholde sig i skriftestolen uden nogen konkret skriftefader, ved fiktion og selvbiografi kunne man løsrive sig fra den personaliserede anden, der var repræsenteret ved det skrevne og trykte udtryks samfundsmæssighed og objektivitet. Individualismen blev skabt »derude« $\mathrm{i}$ udtrykkenes sociale verden. Det skrevne og trykte ord fungerede som en »misdirection« der tillod subjektivt materiale, som ellers var undertrykt eller tæt sammenvævet med andet materiale, at komme frem til overfladen og blive synligt.

Lad os eksemplificere hvorledes læsning og skrivning iscenesætter en objektivering af subjektive fænomener ved at se nærmere på en meget succesrig og trend-skabende roman fra 1794, Ann Radcliffe's The Mysteries of Udolpho. Forfatteren var på nedskrivningstidspunktet omkring tredive år gammel, hun var gift og tilhørte de bedrestillede lag, og levede endvidere i en af Europas mest »moderne « byer, London. Her skrev hun en meget omfangsrig "gotisk « rædselsroman, i min ${ }^{16}$ udgave er den på 672 sider. Men romanens handlinger og oplevelser er både $\mathrm{i}$ tid og i rum fjernet langt fra det nye, borgerlige London. Romanen udspiller sig godt to hundrede år før den tid hvori den er blevet forfattet, og handler om en helt ung kvinde, Emily, der i en stor del af romanen er »fanget $i$ et dystert, gammeldags italiensk slot og føler sig truet af en skurkagtig midaldrende mand. I disse »skrækromantiske« omgivelser hører Emily hele tiden mystiske lyde og har stærke og fremmede følelser og sansninger; hendes forestillingsevne forsyner hende med mange mærkelige billeder, ligesom hendes krop måske er truet af uklare og vagt forståede farer. Samtidig læser hun meget. Men bag alle disse følelser og uklare forestillinger har vi for- 
fatteren, Ann Radcliffe, der roligt sidder på sin stol og skriver og derved koncentrerer en del af sin visuelle opmærksomhed på papiret, mens hun fremkalder alle disse følelser og oplevelser. Med professionel kalkulation udskyder hun over hundredvis af sider heltindens redning og den (delvise) afsløring af mysterierne. Man må formode at Radcliffe var i stand til at foretage en vis psykisk simulering af de beskrevne frlelser og forestillinger samtidig med at hun omhyggeligt udformede intrige, handlingsstruktur og beskrivende passager.

Snart blev mange mennesker $\mathrm{i}$ stand til på en beslægtet måde at forene voldsomme følelser og forestillinger med den stille stol. Ved hjælp af trykkemaskiner kom mysterierne i hænderne på talløse læsere, som energisk læste de mange hundrede sider om trusler, farer og sansninger. Deres opmærksomhed er rettet mod de sorte bogstaver på det hvide papir, hvorved de skaber afstand til »sig selv«, mens bogstaverne og ordene bliver betydere af deres egne »fjerne« kroppe og sanser, som simulerer de betydede følelselser og oplevelser. Læseprocessen er derfor baseret på »misdirection« og sublimering. Selv hvis indholdet af romanen er følelser og oplevelser består budskabet i objektiveringen af kroppens sansninger og i visualiseringen og udskydelsen af begær i den endeløse følge af udtryk der er indskudt mellem krop og omverden. Læseprocessen skaber en relativ følelsesmæssig autonomi ved fiktionens evne til at forsyne læseren med den nødvendige emotionelle støtte. Læserne kan kontrollere og regulere deres følelser og oplevelser, de kan selv bestemme, hvornår de vil vende siden og hvornår de vil flytte øjet til det næste ord. Emotioner og sansninger er blevet løsrevet fra deres forbindelser med kroppen, og fiktionen var således med til udformningen af den emotionelle "idealisme«, der er så karakteristisk for den populære opfattelse af hvad begrebet romantik dækker over. Abstraktion og »idealisme« gjorde det muligt $\mathrm{i}$ et hidtil uset omfang indirekte at betyde krop og bevidsthed.

For yderligere at eksemplificere hvorledes fiktion leverer de usynlige bånd $\mathrm{i}$ beroligelsesstolen ved at tilbyde emotionel kontrol kan vi se på nogle tekster af en anden forfatter, Edgar Allan Poe. Han er en nøglefigur i genrehistorien, fordi han skrev nogle eksemplariske udformninger af de romantiske genrer kriminalhistorien og redselshistorien, og han er yderligere kendt for sine digte. I biografier fremhæves hans romantiske og bohème-agtige liv, men den håndværksmæssige kvalitet $\mathrm{i}$ hans fortællinger og digte viser at han var i stand til at »konstruere sig selv« når han sad på sin skrivebordsstol. For at vise nogle træk ved denne selvkonstruktion vil jeg pege på nogle træk i det berømte 
digt »Ravnen«, i rædselshistorien »Brønden og pendulet« og i kriminalhistorien »Dobbeltmordet i Rue Morgue«.

I digtet Ravnen er stolen det sted, hvor den indre og den ydre verden sammenvaves i symbiose. I digtets indledning står digtets Jeg i sin stue og læser mangent et besynderligt og ejendommeligt bind af glemt $k u n d s k a b$, i tegnsystemer hvor både udtryk og indhold besidder fjernhed og mærkværdighed, da en følge af sansninger begynder at komme til jeg-et, symbolsk forbundet med at det far besøg af en mystisk ravn. Men fremstillingen er tvetydig: kommer den rige folge af sansninger udefra (ravnen banker på døren som var det et rigtigt besøg) eller kommer den indefra, fra erindringer (for eksempel med forbindelser til minder om en død pige, Lenore)? Ved at se ud i verden, ser jeg-et samtidig ind i sin egen melankolske sjæl. Ved tvetydigheden i de symbolske handlinger skaber digtet på en gang distance - ved at forskyde og fremmedgøre, for eksempel ved mystifikationen omkring den mærkelige ravn - og lukning og intimitet. De sidstnævnte folelser frembringes især ved at digtet næsten er overbelastet med allitterationer som omdanner selv udtrykkene til metaforiske kæder og derved simulerer en symbiotisk ikke-arbitraritet i betydningsmanifestationen. ${ }^{17}$ Efter nogen tids forløb sætter jeg-et sig ned i en pudeforsynet stol og efter endnu en stund sætter også ravnen sig, og dens skygge og jeg-ets sjæl forenes. Digtet har været en dynamisk sekvens såvel ved sine semantiske udviklingsforløb som ved rytme etc., og denne sekvens er forbundet med følelsesmæssige bevægelser og udladninger, der delvis fremkaldes ved at sansningernes lokalisering skifter mellem/er tvetydigt placeret i forhold til henholdsvis en indre og en ydre verden. Denne tvetydige oscillering mellem indre og ydre verden er modsat rædselsfiktionen - anvendt til frembringelse af en symbiotisk opløsning af skellet mellem indre og ydre. Stedet hvorfra digtet og digter-jeget medierer den forskelsslettende pendling mellem den indre og den ydre verden er den med puder forsynede stol.

I Poe's kriminalfiktion er målet for denne ikke at frembringe en symbiotisk fusion med, men derimod at opnå en absolut kontrol over omverdenen, og kontrollen udøves i en stol, lejlighedsvis suppleret med nogle få besøg på forbrydelsernes åsted. ${ }^{18} \mathrm{Og}$ Poe er meget bevidst om, at hans projekt er et projekt der går ud på at frembringe et sublimeret mentalt behag. Han påpeger det explicit $\mathrm{i}$ indledningen til »Dobbeltmordet i Rue Morgue«: »På samme måde som manden med den stærke fysik svulmer ved at mærke sin kraft i dens fulde udfoldelse og frydes ved enhver art idræt, der sætter hans muskler i funktion, således beruses analytikeren ved den sjælelige proces, der kaldes efterforskning [which disentangles]. Han finder glæde ved at tum- 
le med endog de mest banale ting, blot de sætter hans særlige evne i svingninger. Han interesserer sig for sådanne opgaver som tydning af gåder, af rebus og af hieroglyfer. Han udfolder ved deres løsning den særlige grad af trafsikkerhed [acumen], der forekommer den almindelige betragter at grænse til det overnaturlige. ${ }^{19}$ Detektivvirksomhed drejer sig om mental handling og kontrol. Fortællingens helt, den berømmelige fader til alle detektiver, Auguste Dupin, er en bogens mand. Sammen med fortæller-jeg-et tilbringer han hele dagen med at læse, at skrive eller at samtale; kun om aftenen tilbringer de nogen tid som voyeuristiske flanører på storbyens gader.

Auguste Dupin's overlegne intellektuelle udfoldelse har selvfølgelig detektion som sit særlige udfoldelsesområde. Og detektionens objekt er psykens, kroppens og kødets mysterier. Mysteriet i Rue Morgue består i at to kvinder er blevet lemlæstede og myrdede under gådefulde omstædigheder; lysten består $\mathbf{i}$ at forklare motiver og gerningsmand til disse sære krops-tegn. Løsningen på mysteriet er, ifølge fortællingen, at forbrydelsen er blevet begået af en Orangutang, det vil sige ikke af en civiliseret mand, men af en dyrisk bevidsthed i en dyrisk krop. I detektivfortællingen udarbejdes der således en objektivistisk historie, der konstruerer en absolut adskillelse mellem bevidsthed og krop, subjekt og objekt. Kroppen og dens affekter eksisterer derude, $i$ byen og i mysterierne omkring forbrydelse og lemlæstelse, hvorimod Dupin og hans ven er rene intellekter der udøver deres kropskontrol ved rolig ræsonnering over de fjerne fænomener. ${ }^{20}$

Dupins efterkommere arvede denne lidenskab for en omverdenskontrol udført ved et skrivebord eller i en lænestol. Dette gælder ikke mindst hans berømteste efterkommer, Sherlock Holmes, og dennes broder Mycroft er endnu mere forelsket i (klub)stolens stille og distancerede ræsonnering. Til tider bliver fortællingernes detektiviske logik og distance helt isoleret fra handling, således at detektiverne bliver voyeurer til emotioner og rædsler uden evne til at gribe ind. ${ }^{21}$ Det er hyppigt blevet påpeget at detektiv-og-kriminalfiktion er det store allegoriske billede på modernitetens og oplysningens projekt. Kriminalfiktion handler om afsøgninger af verden med det formål at frembringe en fuldstændig intellektuel gennemsigtighed i verden og at benytte denne gennemsigtighed til social kontrol. Det er imidlertid samtidig en fiktionstype der handler om at skabe uigennemsigtighed ved at adskille bevidsthed og krop i det objektivistiske fortælleforløb, der placerer kroppen og emotionerne fjernt fra iagttager og læser, således at de kan ses og »nydes«, hvorimod deres sammenhæng med iagttageren/læseren ikke kan forstås.

Poe ydede ikke blot vigtige bidrag til konstruktionen af den moder- 
ne kriminalfiktion om mental kontrol uafhængig af kroppen, han bidrog også væsentligt til udformningen af den fiktionstype der er detektivfortællingernes modsætning: rædselshistorier om kroppe der fuldstændigt bliver kontrolleret af den anden og af den fysiske verden, uafhængigt af de virkningsløse forsøg på mental kontrol. I rædselshistorier som "The Premature Burial«, artikulerer Poe modsætningen mellem bevidsthed og krop og mellem liv og død ved at beskrive en række tilfælde hvor mennesker er blevet begravede levende. Dette fører til helt oplagte begrænsninger af disses evner til at handle, de erfarer den fuldstændige kropslige heteronomi, fremmedstyring. Ved at være indespærrede i grave og kister bliver subjekterne ekstremt opmærksomme på adskillelsen mellem bevidsthed og krop. Forskellen mellem den materielle verden og kroppen er formindsket $i$ en sådan grad at den er på nippet til at forsvinde, hvorfor afstanden mellem den rædselsslagne bevidsthed og kroppen nærmer sig et maksimum. Men på den anden side er bevidstheden om kroppen og dens sansninger på et maksimum og den fremstillede ophidselse er stor. Rædselshistorier ligner mareridt, tabet af kropskontrollen ligner det tab af kontrol over kroppen der finder sted i søvntilstanden. Men Poe's rædselshistorier er skabt med det formål at lade læseren få et vågent og bevidst behag ved at læse om sære kropsoplevelser og ved aktivt at nyde den ekstreme objektgørelse og passivitet. ${ }^{22}$

I en af Poe's andre rædselshistorier, »Brønden og pendulet«, er omvendingen i forhold til detektivernes almægtige og alt-seende subjektposition over for de objektiverede kroppe endnu mere eksplicit. Jeg-et bliver overvåget, fængslet og straffet af en almægtig og usynlig anden. Fortællingens jeg er blevet indespærret $\mathrm{i}$ et torturkammer af den spanske inkvisition. Jeg-ets krop bliver et sted, en »scene«, hvor de usynlige andre kan manifestere deres sociale kontrol over kroppen. I begyndelsen af fortællingen har jeg-et endnu en minimal motorisk kontrol over sin krop. Han kan gå rundt i det snævre torturkammer, selvom mørket forhindrer ham i at fă en klar fornemmelse af størrelsen og formen af torturkammeret. Han prøver at ræsonnerere og kalkulerere for at simulere en kontrol over situationen. Men senere bliver han bundet, og et skarpt pendul bevæger sig langsomt nedad, nærmere og nærmere til hans bundne krop, som også bliver angrebet af rotter. Bevidstheden om at blive overvåget af usynlige kræfter og truslen om lemlæstelse giver jeg-et en uhyre intens, omend negativ selv-oplevelse.

Historien har skabt en platform, fra hvilken det er muligt for læseren at nyde selv den ophidselse og angst der skabes ved truslerne om lemlæstelse og objektgørelse og at nyde oplevelsen af en krop der er 
helt adskilt fra bevidsthedens aktive beherskelse. Lysten ved forskrækkelse eller objekt-gørelse har altid indgået i mange lege, som voksne leger med småbørn (f.eks. ved at sige bøh, svinge eller prikke til dem), og lysten er for børnene størst $\mathrm{i}$ den alder, hvor overgangen fra en overvejende passiv og omverdensafhængig til en mere aktivautonom adfærd finder sted. Udviklingen fra mere passive til mere aktive lystgevinster er imidlertid ikke kun knyttet til det individuelle udviklingsforløb; den mentalitetshistoriske udvikling har medført fremkomsten af langt mere affektivt autonome socialkarakterer og bevidsthedsformer som eksemplificeret i den ræsonnerende detektiv. Den "gotiske« ræedselshistorie med dens beskrivelser af individer der er passive objekter for skæbnens tilskikkelser er da også som angivet i genre-navnet hyppigst henlagt til førmoderne perioder, f.eks. til middelalder og renaissance. Den civilisationshistoriske modsætning mellem førmoderne heteronomi og moderne autonomi spiller en fremtrædende rolle i Bram Stoker's berømte rædselsroman Dracula fra $1897 .{ }^{23}$ Historien fortælles set fra det moderne Londons synsvinkel, fortællere og hovedpersoner er prægede af rationalisme og affektivt set foretager de en kraftig afgrænsning af sig selv i forhold til den anden. Truslerne mod fornuften og den kropslige autonomi kommer fra det tilbagestående Transsylvanien og fra renaissancedespoten Grev Dracula. Hans vampyrprojekt implicerer den totale kropslige sammensmeltning mellem ham og ofret når blodet indoptages $\mathrm{i}$ grevens krop. Han kender magiske og overnaturlige måder der kan få mennesker til at ønske heteronomi og til at ønske blot at være fysisk føde for vampyrer og således at opgive enhver kropskontrol. Den moderne læser er tilskuer til mærkelige urscener hvor subjektet er en mystisk patriarkalsk u-død og objektet er en fremmedgjort krop. Den moderne læser behøver ikke at blive krænket ved at bivåne at personer hengiver sig til en absolut passiv position og opgiver enhver kontrol af kroppen. De kan »nyde« bevidstheden om kroppen som objekt fordi den ikke rigtigt er deres. Vampyrismens og kannibalismens totale synliggørelse af at mennesket er en ting, der af andre kan behandles som et fysisk objekt, sammensmeltes med en myte om den formoderne eksistens. I moderniteten er mennesket bestemt som blot bevidsthed; et muligt bortfald af kroppen er kun et handicap for det enkelte menneske, ikke en essentiel ændring (jfr. f.eks. Johs. V. Jensens fremstilling af det moderne menneske, Homunculus, i Kongens Fald). Den passive kropslige hengivelse er en krænkelse af det moderne, bevidste (voksne) menneskes autonomi, som det kun kan acceptere i forhistoriske gevand ter repræsenteret $\mathrm{i}$ fiktionens kontrollerede form. 
Edgar Allan Poe var i stand til på papir at konstruere lyriske digte der skabte symbiotisk fusion af indre og ydre, kriminalhistorier om intellektuel omverdenskontrol og rædselshistorier om kroppens tingsliggørelse. Han bidrog til raffineringen af affektkontrollen ved i den skriftlige repræsentation at løsrive emotionernernes udtryk og narrative gestaltning fra deres umiddelbare, fænomenale sammenhænge. Kropsautonomi og kropsheteronomi simuleres på siderne, og ligeledes artikuleres opsplitningen i et indre og et ydre rum for samtidig at blive medieret. Ved disse symbolske omformninger og artikulationer skabes der emotive strømme i den moderne læser eller seer, der derved kan få en forlelsesmæssig genopladning. Selvom Poe selv måske ikke var særlig egnet till personligt at klare det moderne og mere intellektuelle og symbolske liv (hans splittede personlighed er som omtalt et yndlingsemne for hans biografer), skabte han mentalt software som gjorde andre mennesker $\mathrm{i}$ stand til at simulere og derved kontrollere følelser i stolens splendid isolation.

Det kan måske forekomme paradoksalt, at den underholdningsfiktion, der normalt opfattes som udtryk for drift-frisættelse, her også ses som et led i drift-regulering, folelsesadministration og sublimering. Paradokset opstår fordi fiktionen som nævnt tidligere på den ene side fremmaner sensuelle oplevelser og aspirationer, men på den anden side muliggør at de kan iscenesættes relativt uafhængigt af mere umiddelbare omverdensrelationer. Den læsende er opslugt i en »narcissistisk « tilstand og vælger som Don Quixote fiktionens virkelighedsiscenesættelse fremfor andre mindre formidlede interaktionsformer. De udløsende udtryk for følelser og begær er transformeret til en form der gør at de aktivt kan artikuleres og kontrolleres af læseren.

For at kunne blive kontrolleret må de affektive udladninger kunne udskydes. Hvis den affektive udladning kommer for tidligt eller er for effektiv (hvilket er karakteristisk for dele af den populære fiktion), er der intet »brændstof « til sublimeringsprocessen. Den kan endvidere som i pornografiens stærke udtryk - henvise til udløsningsformer der befinder sig hinsides læsesituationen. Hvis omvendt graden af sublimering og udskydelse er for høj, medfører det at sublimeringsværkets affektive rødder overskæres hvilket kan være tilfældet i typer af »ikkepopulær« fiktion. Bearbejdningen af de følelsesmæssige og virkelighedsorienteringsmæssige problemer som fremkomsten af den romantiske underholdningsfiktion medførte, står centralt i mange romantiske og efterromantiske fiktionsværker. Romaner som Bristede Illusioner og Madame Bovary bearbejder fascination og frigørelsesbestræbelser i forhold til en romantisk fiktionsverden. Set fra en anden synsvinkel er sådanne værker mediationer, der raffinerer affektiscenesættelsen. De 
romantiske følelses-og-affekt-formninger »citeres« men indlejres i sammenhænge der fungerer som sublimerende bindinger af den romantiske afffektiscenesættelse. Derved bliver »finlitteraturen « i nogle henseender et udtrykssystem, hvis indhold er underholdningslitteraturen, og denne er igen et udtrykssystem hvis indhold er kroppen og dens sansninger.

I såvel litteratur som musik er de affektivt ladede elementer i finkulturen ofte indlejrede emotionelt ladede klichéer fra underholdnings- og populærkulturen. De isoleres fra værkernes øvrige elementer ved verfremdung, elementerne fra populærkulturen fremtræder netop som »citater«, »klichéer« osv. ${ }^{24}$ Et oplagt eksempel på dette er benyttelsen af Mester Jakob-melodien i Mahlers forste symfoni eller brugen af »Ach du lieber Augustin«temaet i Schönbergs Verklärte Nacht, og der er talløse eksempler på den eksplicitte, men indlejrede og isolerede brug af trivia $\mathrm{i}$ modernistisk litteratur og musik, f.eks. i Robbe-Grillet's distancerende og »dekonstruerende nalfiktionsformlen i sine romaner. De følelser der er bundne i citaterne fra populærkulturen kanaliseres ved indlejringen ind i den »seriøse« sammenhæng, hvor de omformes. Den seriøse kunsts budskab kan på et meget højt abstraktionsniveau betragtes som en distanceskabende og »seriøs « omformning af mere umiddelbare lystformer. ${ }^{2.5}$

Et paradigme eller symbol på denne dobbelte indlejring, hvorved forst sanseoplevelser indlejres $\mathrm{i} \gg$ triviel« bogstav-eller billedbåren visuel fiktion, hvorpå fiktionsmønstrene efterfølgende indlejres i mere sublimeret $o g$ »seriøs《 fiktion kan man finde i Kafka's novelle »Forvandlingen«, et centralt værk i den modernistiske kanon. Novellen er på mange måder karakteristisk ved at omlejre og bearbejde massekulturens klichéer. Jeg vil ikke her analysere dette i alle detaljer. Men allerede i novellens indledning bliver vi konfronteret med et stykke massekulturel begærsfremstilling, og i novellen gjort opmærksom på at den massekulturelle begærsartikulation udgør et emotionelt centrum for helten, sælgeren Gregor Samsa. I Samsa's værelse, oven over hans bord, på hvilket hans salgskollektion er placeret, er der et billede: "(..)das er vor kurzem aus einer illustrierten Zeitschrift ausgeschnitten und in einem hübschen, vergoldeten Rahmen untergebracht hatte. Es stellte eine Dame dar, die mit einem Pelzhut und einer Pelzboa versehen, aufrecht dasa 3 und einen schweren Pelzmuff, in dem ihr ganzer Unterarm verschwunden war, dem Beschauer entgegenhob.«

Jeg vil overlade det til læseren at foretage den iøjnespringende freudianske fortolkning af billedet. Hvad jeg derimod vil understrege er det forhold at dette stykke halvpornografisk massekultur fra et 
ugeblad er placeret et vigtigt sted i novellen. Billedet fungerer som et emotionelt centrum for helten; senere i novellen forsøger han endda at »kopulere « med billedet. Da familie og tjenestepige tager billedet væk, forsøger Samsa for første og eneste gang at gøre modstand mod omgivelsernes handlinger, der påfører ham skam og stigmatisering. Men forfatteren lader selvfølgelig kampen være futil, Samsa tvinges til at opgive sit vulgære, anonyme og begærmættede billede. Som det klart fremgår i den moderne visuelle kunst, er modernismen en bestræbelse på at opnå en absolut abstraktion og sublimering, idet den hyppigt bearbejder populærfiktionens og populærkunstens relative abstraktioner for at skabe homo aesteticus, mennesket der er i stand til at foretage en sublim sublimering. Fremstillingen af f.eks. menneskelegemet og menneskeansigtet foretages i reklamernes og massekulturens degraderede regie, hvor grænsen mellem den autonome æstetiske oplevelse og andre interaktionsformer er flydende; mennesket kan kun indgå i den seriøse kunst som citat eller i stærk stilisering.

Jeg vil slutteligt præcisere, hvad jeg mener med udtrykket mentalt software. Bevidstheden kan opfattes som en formidlende instans mellem krop og omverden. Den bearbejder og ordner sansningerne $i$ systemer og forløb, og disse systemer bruges (bl.a.) til at regulere den motoriske reaktion på givne input. Lavtstående organismer er karakteriserede ved en meget høj grad af biologisk forprogrammering, »instinkt«-formning, af sammenhængen mellem input og output, hvorimod højerestående organismer supplerer de forprogrammerede reaktionsmønstre med programmer opbygget i socialisationsforløbet. En del af disse erhvervede "programmer « opbygges ved individualiseret interaktion, men en meget stor del består i erhvervelsen af kulturens sociale programmer, der som de biologiske programmer formidles over tid, men som modsat disse ikke er indkodet i generne, men derimod i de sociale institutioner i vid forstand, hvilket muliggør en langt mere fleksibel omkodning. Mennesket er en ekstremt »kulturel « organisme, fordi dets nervesystem (der har udviklet »bevidsthed «) biologisk set er så ubestemt og derfor kræver supplering med individuelle og kulturelle mentale programmer for at kunne fungere. Nogle sanse-data ordnes på en bestemt măde, således at de kan fungere som udtrykssystemer, som regulatorer for andre sanse-data og for handlingsmønstre. Selv et så biologisk funderet fænomen som seksualiteten kræver opbygning af repræsentationssystemer i socialiseringsforløbet for at kunne komme til udløsning. Der er ingen total forprogrammering mellem e.g. krop og mulige ydre objekter, kun en mængde af mulige programmuligheder (e.g. homosexualitet, hetero- 
seksualitet). Udviklingspsykologien, psykoanalysen og mentalitetshistorien beskriver de typiske "programmer", f.eks. karaktertræk, traumer osv. der dannes ved typiske interaktioner med omverdenen (f.eks. ved at relationer til historisk typiske, konkrete fædre danner udtryks-og-reaktionsmønstre som de hæmmende og regulerende udtryksfelter der i psykoanalysen kaldes over-jeget). Forholdet mellem krop, bevidsthed og omverden, der danner grundlag for individernes affektive »økonomi« reguleres således af »programmer«, bestående af sekvenser og mængder af perceptoriske kvaliteter. Selv så enkle aktiviteter som at »gå«, »grave«, »klø sig« osv. kræver »lyst « til at udføre handlingen, ligesom forholdet til »den anden « kræver formidlende, motiverende og regulerende »lyst «/»ulyst《-strukturer. For ikke at tale om udførelsen af komplicerede sociale aktiviteter, der kræver mentale handlinger såsom at »løse matematiske problemer", "skrive videnskabelige artikler«, overvåge fremstillingen af chips osv. Den affekt-mæssige omrokering $\mathrm{i}$ individet må tænkes at følge "programmer «, sekvenser af »forestillinger« der, hævder jeg, har en stor lighed med en række karakteristiske fiktionsstrukturer (ikke fordi fiktionsværkerne »fremstiller « og »afspejler« disse, men fordi de i en række henseender er ligedannede). Uden konstruktion ville omverdenen være en flad og kaotisk samling sanseindtryk uden affektive kvaliteter; konstruktioner samordner meddelelserne fra de forskellige sanser og forskyder de affektive kvantiteter mellem disse. Som vi så ved Poe's benyttelse af forskellige fiktionsformer, består væsentlige dele af fiktionens funktion i omformninger af relationerne mellem bevidsthed-krop-omverden med de deraf følgende genereringer af effektive strømme (projektioner, introjektioner osv.) ved narrative sekvenser af sanseelementer. I det 19. århundredes forestillinger om dannelse og kultur var der en stærk understregning af bevidstheds-og følelseslivet som et socialt udviklingsarbejde, hvorimod fremherskende strømninger i det tyvende århundredes kulturelle liv har bygget på forestillinger om et Rousseau-agtigt "naturligt « bevidstheds-og-følelsesliv som kulturen skulle forsøge at genfinde bag de forskellige fremmedgørelsers forvrængninger. ${ }^{26}$

Lévi-Strauss' myte-og-mediationsbegreber indeholder forestillinger om at forholdet mellem bevidsthed og omverden konstrueres på baggrund af mønstre af elementer fra den sansbare verden. Myter er ikke simple repræsentationer og afspejlinger af den ydre verden, og de er heller ikke »fantasiprodukter « i den normale betydning af »fantasi« som ensbetydende med frie påfund. Myterne er mediationer, formidlinger, dvs. udtrykssystemer dannet af den sansbare verden, der danner et system af relationer, der forbinder mennesket med verden. 
Når f.eks. Pueblo-indianerne formidler mellem liv og død ved først at forskyde modsætningen til tre-heden agerbrug/jagt/krig og efterfølgende formindsker forskellene ved at forskyde disse til treheden græsædende dyr/ådselædere/rovdyr, er mediationerne nogle bestemte ordninger af, programmeringer af sansedata. Den mytiske tankevirksomhed består i en (om)arrangering af sanse-enheder i bestemte konfigurationer og forløb. Dette er ikke en totalt ubunden opgave, for mytemageren, bricoleuren, er sat $\mathrm{i}$ en bestemt situation hvor nogle bestemte elementer er for hånden, men det er heller ikke en totalt bunden opgave, idet elementerne muliggør en række forskellige kombinationer, »løsninger«, »myter«. For Lévi-Strauss var myter og fiktion en forholdsvis »interesseløs erkendelse« der bearbejdede kropsløse, perciperede modsætninger (han forsøgte at »fortrænge inspirationen fra Freud).

For psykoanalysen drejer myter og fiktion sig ikke om en kropsløs erkendelse løsrevet fra affekterne. Men for Freud og for mange senere psykoanalytikere var perspektivet på myter og især på individuelle kunstværker overvejende tilbageskuende, værkerne var spor, der pegede på rødder og oprindelse. At se dem som strukturer der er funktionelle i produktionens og konsumptionens nutid spillede en mindre rolle. Tilsvarende i litteraturvidenskabens fortolkning af fiktion, der som regel går ud på en kognitiv forklaring (værk $\mathrm{x}$ betyder $\mathrm{y}$ ) der peger væk fra det funktionelle nu for læse-eller-kigger-oplevelsen i stolen (værk x frembringer det perceptoriske, lyst-ulyst-artikulerende forløb y). Kun i den platte underholdning er stolens lyst en legitimation i sig selv, medens den i »seriøse« aktiviteter opfattes som udtryk for virkeligheder, der er placeret andetsteds.

Jeg har brugt ordet "simulering « for at beskrive fiktionens bearbejdning af perceptioner og erindringer med henblik på at frembringe affektive virkninger. Jeg vil understrege at min benyttelse ikke har nogen forbindelse med Baudrillards udtryk simulacre og dette begrebs noget vulgære opstilling af en modsætning mellem »virkelighed « og menneskeskabte repræsentationer, der tænkes i begreber såsom »uvirkelig« og »illusion«. At mennesker i nyere tid har en mere aktiv og bevidst rolle i fabrikationen af den symbolske formning af deres affektive og kognitive relationer til den fysiske og den sociale verden end de gjorde i de gode gamle dage, hvor mennesket var et mere passivt objekt for naturens luner, har gjort disse medierende relationer mere synlige, og de har derved klart ændret karakter. Men de menneskeskabte mediationer - f.eks. fiktions mediationer - er ikke mindre virkelige end fortidens mediationer, og menneskets forhold til omverdenen er altid allerede et medieret forhold, hvadenten mediationerne 
opbygges på grundlag af interaktionen med en naturlig eller en kulturel verden. Når der i nærværende artikel er benyttet udtrykket »uformidlet« må der herved forstås en lav grad af kulturel formidling. Hvadenten man ser solen i fjernsynet eller i naturen er retinas lysperceptioner i begge tilfælde kun »tegn« der må fortolkes og som henviser til et fysisk objekt, der i ordets egentligste betydning befinder sig »uden for rækkevidde « af beskueren og som derfor i mange aspekter må konstrueres mentalt. Når man kan registrere at fiktionen tager sit udgangspunkt i fjernsanserne syn og hørelse i dens individuations-og sublimeringsprojekt, kan det ikke i sig selv give anledning til normative (rousseau-istiske) betragtninger, men kun til konstatering af mentalitetshistoriske accentforskydninger, ${ }^{27}$ af at livet i stolen er anderledes end livet på marken eller i skoven.

Modsat hvad f.eks. Adorno og andre modernistiske teoretikere mente, arbejder fiktion og æstetik i højere grad som en del af modernitetens udviklingsprojekt end som en udenforstående kritisk instans. Kunst og fiktion er ikke så forskellig fra andre elementer i moderniseringsprojektet såsom naturvidenskaberne. Naturvidenskaberne bearbejder formidlingerne mellem mennesket og naturen og skaber forudsætninger for en mere effektiv naturbeherskelse. Fiktion skaber affektive og sociale modeller og formidlinger og skaber derfor forudsætningerne for mere effektive former for psyko-fysisk regulering. I tidligere tider blev det mentale software installeret $\mathrm{i}$ individet i den konkrete socialiserings programmeringsproces, nu installeres det bevidst af høj-og-lavkulturens bevidsthedsproducenter og bevidsthedsadministratorer og under den enkeltes bevidste medvirken. ${ }^{28}$ Livet i stolen er ikke blot en indlæring i passivitet; individualiseringen af kontrollen over følelseslivet gør stolen til et førersæde, hvor styringen af affekterne løsnes fra bindingerne til den konkrete anden.

\section{Noter}

1. Denne danske oversættelse af tranquilizing besidder desværre ikke helt så tæt en konnotativ forbindelse til »nervemedicin«, beroligende middel, som ordets engelske original, der for den moderne læser let konnoterer »tranquilizer«.

2. Cf. Mette Overgaard Gotthardsen: „Drømmebilleder« i Kultur G Klasse nr. 51 om musikkens socialpsykologiske udvikling.

3. London 1982. I Danmark har Martin Zerlang beskxftiget sig med skriftlighedens rolle i den mentalitetshistoriske udviklingsproces, f.eks. i En Selvskreven historie, Kbh. 1982 og i artikler i Kultur \& Klasse nr. 32,33 og 48.

4. Cf. også Peter Larsen i Kultur $\mathscr{E}^{\circ}$ Klasse nr. 48 om Pierre Francastel.

5. I hans Üher den Prozeß der Zivilisation (1936) 2.udg. Bern 1959. 
6. Chicago 1982.

7. Selvom høresansen kan formidle fænomener, der har deres kilde fjernt fra den hørende, er oplevelsens fanomenale forbindelse med afsenderen og med rummet langt svagere end for synets vedkommende.

8. Paris 1966.

9. I hans bog Understanding Media, N.Y. 1964. Jeg tager selvfølgelig alle mulige forbchold overfor McLuhan's bog og dens hastige generalisationer, men hans understregning af betydningen af et givet mediums almene egenskaber og af den indvirkning disse har for modtagelsen af et givet budskab på et givet tidspunkt gør bogen til en vigtig forskningsmæssig inspirationskilde.

10. T. Sebeok (udg.): Style in Language, M.I.T. (1960) 1966, p.354f.

11. Hvor fiktion i al almindelighed fik navn efter sin skrevne/trykte form.

12. Ong har taget udtrykket verbo-motorisk fra Marcel Jousse: Le Style oral rhytmique et mnémotechnique chez les Verbo-moteurs, Paris 1926, og det fæenomen han forsøger at beskrive er beslægtet med virkelighedsbaggrunden for de lingvistiske fænomener illocutionære og og perlocutionare talehandlinger som John Searle og andre har beskrevet.

13. Forfattere har ofte varet meget opmarksomme på dette forhold og har ad nauseam beklaget sig over deres folelse af fremmedgørelse frembragt ved deres professionelle brug af private følelser som et rămateriale, der bearbejdes og fremstilles »derude« $\mathrm{i} »$ sidernes« (kunstens) objektivitet.

14. Cf. E.A. Havelock: Preface to Plato, Oxford 1963.

15. Cf. Michel Foucault: La volonté de savoir, Paris 1978. Her beskrives den moderne vækst i diskurser om krop og seksualitet med deraf følgende samfundsmassiggørelse af disse fanomener.

16. The Worlds Classics.

17. I mundtlig fiktion er allitterationer typisk en mnemoteknisk hjalpekonstruktion der understreger den fysiske karakter af betydningssystemeìne. Men Poe benytter allit terationerne til det modsatte formål: han forsøger at sammensmelte udtryk og indhold på en sădan mảde at det fremtræder som en negering af forskel, ligesom alliterationer nu hyppigt opfattes som et aspekt af en "barnlig-uskyldig« ludisk symbiose af form og indhold.

18. Cf. Jorgen Holmgaards analyse »Poe og »Mordene i Rue Morgue«, i: Holmgaard/Michaëlis(red.): Lystmord, Kbh. 1984.

19. Gyldendals Traneboger s. 50 oversat af Otto Rung.

20. Adskillelsen af og afpersonaliseringen af forholdet mellem subjekt og objekt er del af bred social udvikling $\mathrm{i}$ det attende og det nittende århundrede. I "Dobbeltmordet i Ruc Morgue er det vigtigt for Poc at understrege forbindelsen mellem detektivens, Auguste Dupin's overlegne egenskaber som detektiv og abstrakte og upersonlige videnskaber såsom fysik, logik og matematik, jfr. Jørgen Holmgaard "Poe og "Mordene i Rue Morgue«". I fortællingen "The Mystery of Marie Roget« er fortællingen taet forbundet med en betydningsfuld moderne institution, Avisen, og dennes synsvinkel på forbrydelse. I de moderne samfund foregik vaksten i beskrivelserne af naturen som styret og reguleret af upersonlige naturlove i sammenhang med vaksten i socialc institutioner som tvang mennesket til at adlyde upersonlige menneskelige love. Fremvaksten af det moderne retssystem og af politiet medførte at den enkelte ikke mere blev overvăget af lokale og personlige instanser, men derimod af nationale og anonyme; Loven og de øjne der overvågede den enkeltes driftregulering lossev sig fra en personaliseret inkarnation.

21. Jfr. Holmes-fortallingen »Den græske tolk“, jfr. iøvrigt Grodal : »Sherlock Holmes - En professionel voyeur«, i Lystmord, Kbh. 1984.

22. For en mere detaljeret fremstilling af passiv-positionens lystgevinster se Grodal: »Fiktionsteori og underholdningens genrer«, i Kultur $\mathcal{F}^{\circ}$ Klasse nr. 58.

23. Den fiktionsmassige benyttelse af tvetydigheden mellem det »naturlige« og det »overnaturlige $\mathrm{i}$ form af litteratur der er fantastisk i Todorovs forstand (jfr. hans Introduction à la littérature fantastique, Paris 1970) er et moderne fænomen. Den fantastiske litteratur i denne forstand stammer fra slutningen af det 18 århundrede, ligesom overgangen fra overnaturlig og evcntyrlig til fantastisk børnelitteratur finder sted i begyndelsen af det 19. århundrede, (jfr. condnu uudgivet liccntiatafhandling af Hannc Brøbeck Kbh. 1987). 
24. Cf. Grodal: $\gg$ Framing, Intertext, Metatext and Television Fiction; With Exemplifications from "Moonlighting «, in Pre-Fiew, Stockholm 1989.

25. Indlejrings-omskrivningsfænomenet har samtidig forbindelse til det fænomenkompleks som man kunne kalde den litterære og æstetiske socialisering. Eventyr og enkle melodier er de forste stetiske former som barnet stifter bekend tskab til i socialiseringsforløbet. Disse former bliver derved tæt sammenvævet med tidlige affektive lag i individet. Efterfølgende fascinationer bliver derfor indskrevet oven på disse tidligere lag. En roman som Pontoppidans Lykke-Per er således meget eksplicit markeret som et forsøg på at skrivc en realistisk roman henover de underliggende eventyr-formede fascinationer. Ved senere overlejringer af tidligere estetiske former sker der samtidig en modifikation af disse efter det princip som Freud $\mathrm{i}$ anden sammenhæng har beskrevet som nachträglichkeit-princippet.

26. Karakteristisk i denne sammenhæng er psykoanalysens janus-agtige splittelse mellem naturaliserende og kulturaliserende forestillinger. Selv om Freud selv forbandt et psykologisk og mentalhistorisk perspektiv med forestillinger af en mere drift-og-psyke-naturaliserende aspekter, har store dele af især den populære effekt af psykoanalysen været en krops-ogdrift-naturalisering.

27. I Aldous Huxleys tvetydige science fiction rædselshistoric Fagre ny verden om »la condition postmoderne« forudsá han at udviklingen i massekulturen ville udarte sig til et kampemæssigt desublimeringsprojekt, for eksempel symboliseret i romanens fremstilling af den totale bio-graf $\mathrm{i}$ hvilken selv folesansen blev stimuleret af underholdningsindustriens tegnmaskiner. Men en sådan desublimering er endnu ikke blevet virkeliggjort, ikke engang i det moderne smagsløgsteater, restauranten, hvis artikulation af smagens nærsans er baseret på ritualisering, udskydelse og evnen til at distingvere. Massekulturen er stadig baseret på fremstillingen af nærsansere ved hjælp af fjernsanserne.

28. Jeg har med ovenstående ikke slet og ret accepteret bevidsthedsindustriens nuværende forvaltning, men at intervenere i kulturprocesserne forudsætter at man endegyldigt opgiver forestillingen om en menneskelig natur, hvadenten forestillingen er en rousseauistisk forestilling om en uskyldig og hel, førmodeme menneskelighed, eller deri som i Marx' fremmedgørelsesbegreb fremstår negativt $i$ og med mennesket under kapitalismen afviger fra et hypotetisk ikke-fremmedgjort menneske. Historisk set forsøger de fleste kritiske og emancipatoriske bevægelser at legitimere ændringerne ved at beskrive dem som sigtende mod at foretage en tilbagevending til et historisk tidligere stadium. I forestillinger om undertrykkelse er der indbygget forestilling om en tilstand for noget blev undertrykt. Økologiske bevægelser drommer om en retablering af en tidligere okologisk balance, seksual-emancipatorer har forestillinger om en naturlig seksualitet, mange fortalere for kvindeemancipation har forestillinger om nødvendigheden af en tillagevending til en kvindelighed før patriarkatet osv. Den lange udviklingsproces fra urhavet via mikrober og menneskeaber og via den menneskelige historie frem til det 20.århundredes menneske er imidlertid et åbent projekt, hvor alle parametre, fra krop til psyke og emotioner er under bestandig omdannelse og rekonstruktion. Tidligere tiders langsommere evolutionshastighed tilslørede i højere grad den historiske relativisme. Men i en tid hvor oceaner skal passes som køkkenhaver og bevidsthedslivet omdannes af gigantindustrier er det blevet evident at en absoluterende og statisk natur-forestilling er blevet meningsløs. Forestillinger som lighed (kønslig, klassemæssig osv.) er derfor utopisk projekter, der skal bedømmes på deres ønskværdighed og på betingelserne for deres gennemførelse, ikke på deres grad af mnaturlighed « (processerne frem mod målet ændrer måske totalt opbygningen af de individer der deltager i dcm. 